\title{
Research Article \\ IDENTIFICATION AND CHARACTERIZATION OF CAUSAL AGENT OF CERCOSPORA LEAF SPOT DISEASE OF OKRA
}

\section{S.M. ZIA HASAN'1, MD. FIROSE HOSSAIN1', ZANNATI FERDOUS ZAOTI', MD. SAROAR JAHAN', MD. FARUK HASAN', MD. ASADUL ISLAM ${ }^{1}$ AND BISWANATH SIKDAR ${ }^{1,2^{\star}}$}

1Department of Genetic Engineering and Biotechnology, Faculty of Life and Earth Science, University of Rajshahi, Rajshahi-6205, Bangladesh

1,2Professor Joarder DNA \& Chromosome Research Lab, Department of Genetic Engineering and Biotechnology, Faculty of Life and Earth Science, University of

Rajshahi, Rajshahi-6205, Bangladesh

*Corresponding Author: Email-ziahasan0707@gmail.com, sikdar2014@gmail.com

Received:February 08, 2018; Revised: February 27, 2018; Accepted: March 01, 2018; Published: March 30, 2018

\begin{abstract}
In august 2017, symptoms of leaf spot disease were found in okra (Abelmoschus esculentus L.) cultivated area of university of Rajshahi. Several morphological and biochemical tests were conducted for the identification and characterization of the causal agent of leaf spot disease of okra. The pathogen was isolated from infected leaf and morphological identification initially confirms the presence of the fungi of Cercospora spp. For the growth profiling, the fungi was grown in different media, temperature, pH, sugar concentrations, acid concentrations (Citric, Malic and Nicotinic Acid) and different carbohydrates (sucrose, fructose, maltose, glucose, lactose). The optimum growth of the fungi was observed at $25^{\circ} \mathrm{C}, \mathrm{pH} 6$ and $20 \%$ sugar concentration. The highest $43 \pm 0.3 \mathrm{~mm}$ radial colony growth was observed in Sucrose and Maltose with $0.457 \mathrm{gm}$ and $0.435 \mathrm{gm}$ dry weight. The fungi could not grow at $2 \%$ concentration of citric and malic acid. Cellulolytic activity was not observed for this strain. A BlastN search of $511 \mathrm{bp}$ obtained sequenced region was performed in NCBI GenBank database and it revealed that, the strains had approximately 90\% similarity with several Cercospora spp. The obtained sequence deposited in GenBank (accession No. MG735450).
\end{abstract}

Keywords- Abelmoschus esculentus, Cercospora leaf spot, okra, fungi, Cercospora abelmoschi.

Citation: S. M. Zia Hasan, et al., (2018) Identification and Characterization of Causal Agent of Cercospora Leaf Spot Disease of Okra. International Journal of Microbiology Research, ISSN: 0975-5276 \& E-ISSN: 0975-9174, Volume 10, Issue 3, pp.-1015-1019. DOI: http://dx.doi.org/10.9735/0975-5276.10.3.1015-1019

Copyright: Copyright@2018 S. M. Zia Hasan, et al., This is an open-access article distributed under the terms of the Creative Commons Attribution License, which permits unrestricted use, distribution and reproduction in any medium, provided the original author and source are credited.

Academic Editor / Reviewer: Dilruba Sarkar, Singh S. P., Md. Enamul Haque

\section{Introduction}

Okra (Abelmoschus esculentus L.) belongs to the family Malvaceae is cultivated in tropical, subtropical and warm temperate regions around the world. It is one of the most important vegetable crops extensively cultivated in Bangladesh. It is known as lady's finger, gumbo or ochro in many English speaking countries. The local name is known as Dhedosh or Bhendi. Okra is specially valued for its tender, fibrous and delicious fruits as a vegetable. These fruits are rich in vitamins, calcium, potassium and minerals. It is good for people suffering from renal colic, leucorrhoea, chronic dysentery, diabetic, inflammation and general weakness [18]. It has been used in various purposes as dietary fiber, oil production, making paper, animal feed [9-12]. The dry fruit shell and stem containing crude fiber are suitable for manufacture of paper and card board.

In 2014-2015, Bangladesh produced 51,885 metric tons of okra in 28,046 acres of land. An average yield was 1.850 metric ton [13]. Every year Okra is affected by several viral, bacterial and fungal diseases like yellow vain mosaic virus, enation leaf curl virus, leaf spot, Fusarium wilt, damping off, powdery mildew, Alternaria leaf blight etc., and caused yield loss in Bangladesh. Other diseases of okra are blossom and fruit blight seedling disease, cotton root rot, charcoal rot, southern blight. Cercospora leaf spot (CLS), a fungal disease of okra caused by different Cercospora spp. like Cercospora abelmoschi, Cercospora malayensis, Cercospora hibisci [14-17]. This disease is considered to be the most destructive disease that can appear at any growth stage of the plant.

In august 2017, symptoms of leaf spot disease were found in okra (Abelmoschus esculentus $L$.) cultivated area of university of Rajshahi. Symptoms on leaf surfaces were found sooty black, angular spots, black mould at upper surface. So, the aim of this study was isolation, identification and characterization of the pathogen responsible for this leaf spot disease based on morphological, biochemical test and molecular analysis.

\section{Materials and Methods \\ Collection of the infected plant part and isolation of the pathogen \\ The leaf spot infected plant leaves were collected according to sign and symptoms of the disease from okra field of university of Rajshahi, Bangladesh [Fig-1a] [17- 22]. The spoiled leaf parts were cut into small pieces. Surface sterilization of collected diseased leaf parts were done by dipping in 10\% sodium hypo chloride solution for $2 \mathrm{~min}$ and rinsed in sterile water. After that, it was placed on PDA (potato dextrose agar) media. By continuous subculture, the individual fungal strains were isolated.}

\section{Morphological and microscopic identification}

The morphological observation of the isolate was done using PDA (potato dextrose agar) media purchased from 'Himedia, India'. From periphery of an actively growing culture on PDA, a mycelial disc of $6 \mathrm{~mm}$ diameter was cut and was placed at center of new PDA media containing petri dish. The petri dishes were kept for incubation in dark at room temperature $\left(25^{\circ} \mathrm{C}\right)$ for 7 days. Colonies on each medium were compared for their diameters, overall colors, colors of conidia, texture, form, margin, reverse colors, elevation, opacity, dry weight, sporulation and zonation etc. The isolates were also subjected to microscopic 
analysis for their characterization and identification under light microscope at 40X magnification (LABOMED LX400).

\section{Growth profiling in different temperatures}

For the optimization of temperature, four petri dishes with around $25 \mathrm{ml}$ PDA media were used. The $6 \mathrm{~mm}$ mycelial discs of the isolated strain from pure culture were placed at center of four petri dishes. Then the four petri dishes were kept in $4^{\circ} \mathrm{C}, 25^{\circ} \mathrm{C}, 30^{\circ} \mathrm{C}$ and $35^{\circ} \mathrm{C}$ temperature respectively and incubated at dark for 7 days. After 7 days colony morphology, characteristics and dry weight was observed

\section{Growth profiling in different $\mathrm{pH}$}

Five culture bottles were used for the optimization of pH. Each bottle had $100 \mathrm{ml}$ of manually prepared potato dextrose broth media. Then the $\mathrm{pH}$ of the medium of different bottles was adjusted at 5, 6, 7 and 9 respectively with $\mathrm{HCl}$ and $\mathrm{NaOH}$ prior to sterilization. After sterilization the culture bottles were kept in laminar flow hood (Esco Technologies, Inc., USA) for cooling down. The $6 \mathrm{~mm}$ diameter mycelial discs were cut from a pure culture on PDA media and inoculated in the culture bottles. Then the bottles were incubated in room temperature in dark for 7 days. After 7 days, the dry weight was measured using electrical balance (AR 3130 Ohasu Crop, Pine Book, NJ, USA.) by collecting the fungal mycelium and by drying them at $40^{\circ} \mathrm{C}$.

\section{Growth profiling in different sugar concentrations}

Normally the media is used as $20 \%(20 \mathrm{gm} / \mathrm{L})$ sugar concentration. For the growth profiling in different sugar concentrations, manually prepared PDA media was used with different sugar or dextrose concentrations. Different dextrose concentrations - $5 \%$ (5 gm/L), 10\% (10 gm/L), 15\% (15 gm/L) and 20\% (20 gm/L) were used. All other components were same as previously mentioned. The boiled media without the sugar was transferred to four conical flasks each containing 50 $\mathrm{ml}$ media. Then sugar was added as previously mentioned concentrations in separate conical flasks and sterilized. These sterilized media with four different sugar concentrations were poured into four sterilized petri dishes in an amount of about $25 \mathrm{ml}$ each respectively. Using cork borer mycelial discs were cut and placed at the center of all petri dishes. Then the petri dishes were incubated in room temperature in dark for 7 days. After incubation the colonies morphological characteristics and dry weight were observed.

\section{Growth profiling in different carbohydrates}

PDA media was prepared manually according to the previously mentioned procedure. Instead of dextrose, different carbohydrates (fructose, sucrose, glucose, maltose and lactose) were used at $20 \mathrm{gm} / \mathrm{L}$ concentration. Mycelial discs were transferred at the center on the media and incubated at room temperature in dark for 7 days. After 7 days, the characterization study and the dry weight were measured.

Growth profiling in different citric, malic and nicotinic acid concentrations Potato dextrose broth media was used to study the effect of citric acid on the growth of isolated fungi. For this, four different concentrations $(0.25 \%, 0.5 \%, 1 \%$ and $2 \%$ ) of citric, malic and nicotinic acid was used. In this case $1400 \mathrm{ml}$ broth media was prepared and transferred to 13 culture flasks, so that each contains $100 \mathrm{ml}$ media. Among them citric, malic and nicotinic acid were added in 12 conical flasks at different mentioned concentrations separately and marked for later identification. As a control, an additional conical flask with broth media was used without any acid to compare the growth of the isolated strain with the growth in normal liquid media. Mycelial discs of pure culture from PDA were transferred to each flask. The bottles were wrapped well using Aluminium foil and rubbers and allowed to incubate at room temperature for 7 days. After the incubation period the dry weights were recorded.

\section{Study on cellulolytic activity}

A cellulose strip of $6 \mathrm{~cm} / 1.5 \mathrm{~cm}$ was used to study the cellulolytic activity. For this study, the strip was placed in the liquid culture of the fungus before incubation.
After 7 days, the activity was observed.

\section{Fungal genomic DNA isolation and sequencing}

All Prep Fungal DNA/RNA/Protein Kit (QIAGEN)' was used for the isolation of the genomic DNA followed by their 'Quick start- protocol'. The quality and quantity of the DNA was checked electrophoretically and spectrophotometrically.

Then the isolated DNA was subjected to the PCR amplification using universal primers 'ITS-1' and 'ITS-4' (Sigma, USA) and DreamTaq Green PCR Master Mix (2X) (Thermofisher). PCR was performed in a $50 \mu$ l reaction mixture containing $25 \mu$ l of DreamTaq Green PCR Master Mix (2X), $2.0 \mu \mathrm{L}$ of forward and reverse primer, $3.0 \mu \mathrm{L}$ of genomic DNA and rest of the PCR water.

PCR program (Q-cycler 96, Hain Life Science) was as follows: an initial denaturation step at $94^{\circ} \mathrm{C}$ for $3.30 \mathrm{~min}$, followed by 35 cycles of denaturation at $94^{\circ} \mathrm{C}$ for $1 \mathrm{~min}$, primer annealing at $52^{\circ} \mathrm{C}$ for 30 seconds, primer extension at $72^{\circ} \mathrm{C}$ for $1 \mathrm{~min}$. Final extension at $72^{\circ} \mathrm{C}$ for $10 \mathrm{~min}$ and hold at $4^{\circ} \mathrm{C}$. Amplicons were separated by agarose gel electrophoresis $(1 \%)$ in $0.5 \mathrm{X}$ Tris/borate/EDTA buffer. The quality and quantity of the DNA was checked electrophoretically and spectrophotometrically. Products of sequencing reactions were analyzed in Malaysia Ltd. via Invent Biotech, Bangladesh. Sequence analysis was performed using a BlastN search of GenBank of NCBI analysis software and database from their website.

\section{Statistical analysis}

All the above experiments of the present study were conducted in triplicate consistency of results and statistical purpose. The data were expressed as mean

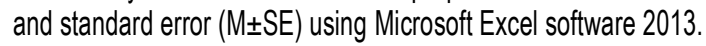

\section{Results}

\section{Isolation of fungi}

The fungi were isolated from the infected leaf of okra. At the incubation period, the fungal colony was appeared due to mycelial growth of the fungi. At the first stage, the colony appearance looked like white cottony to fluffy [Fig-1b], later stage it undergoes to brownish color [16, 23-26].

\section{Morphological and microscopic identification}

The development of mycelia on PDA media is considerable important for the detection of colony morphology. In PDA media, it was white to brownish and white with light pink pigment on reverse side [18]. Microscopic observation showed that, the conidia was very long and multi-septate, conidia were pale olivaceous brown and septate [Fig-1c-d] [14, 15, 17, 27-29].

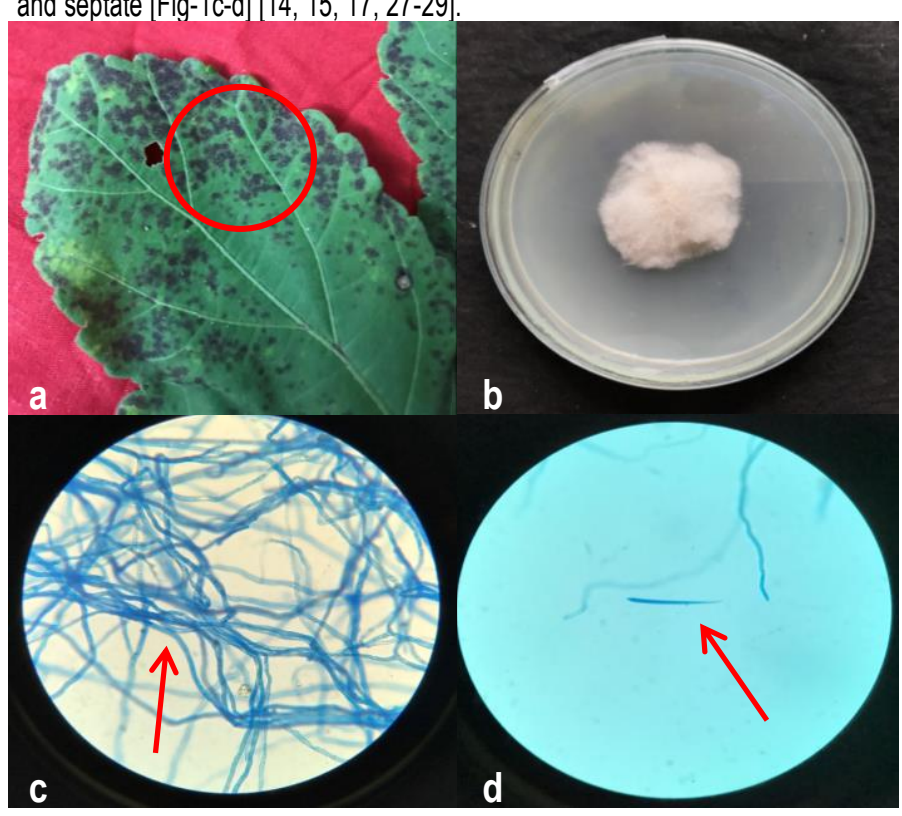

Fig-1 (a) Cercospora leaf spot disease of okra, (b) isolated fungi on PDA medium, (c) mycelium stained by lactophenol cotton blue, (d) conidia at $40 \mathrm{X}$ magnification 

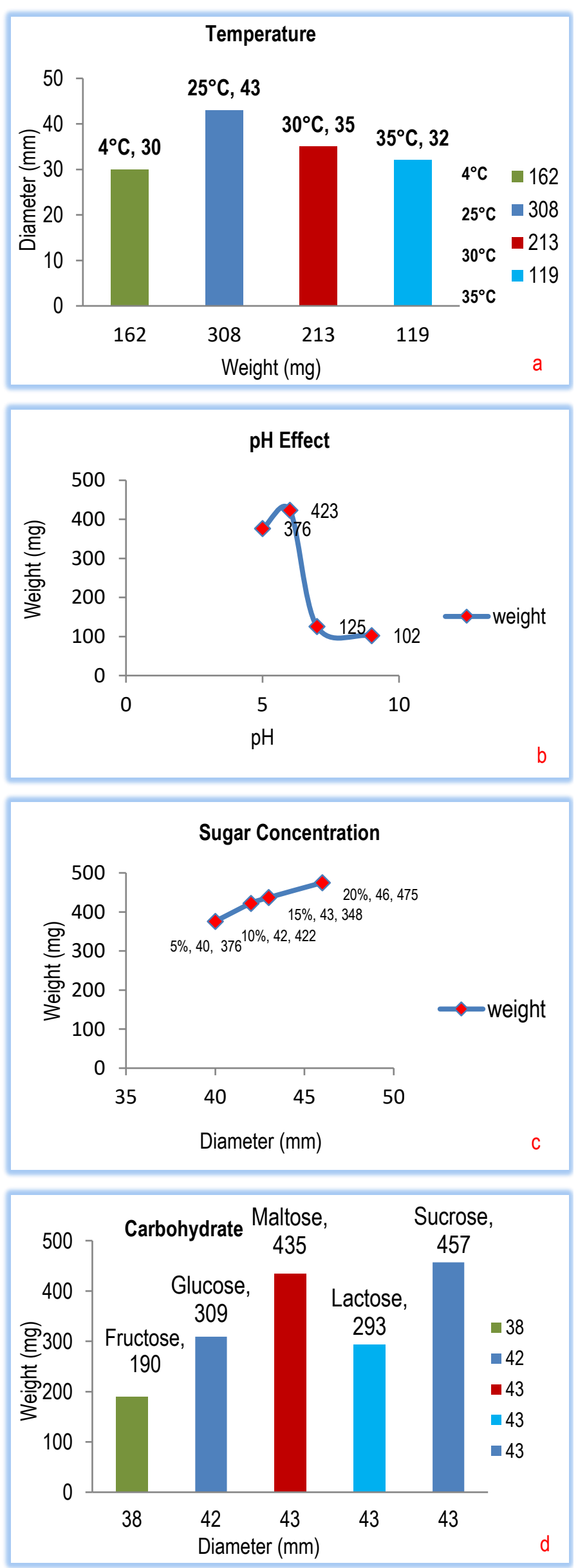

Fig-2 Growth profiling of isolated fungi at different (a) temperature, (b) pH, (c) sugar concentration and (d) carbohydrate

\section{Growth profiling in different $\mathrm{pH}$}

To check the effect of $\mathrm{pH}$, the fungal samples were grown at different $\mathrm{pH}$ ranges. At pH 5, 6, 7 and 9 the colony radial growth was observed $40 \mathrm{~mm}, 43 \mathrm{~mm}, 26 \mathrm{~mm}$ and $20 \mathrm{~mm}$ with $0.376 \mathrm{gm}, 0.423 \mathrm{gm}, 0.125 \mathrm{gm}$ and $0.102 \mathrm{gm}$ dry weight respectively [Fig-2b].
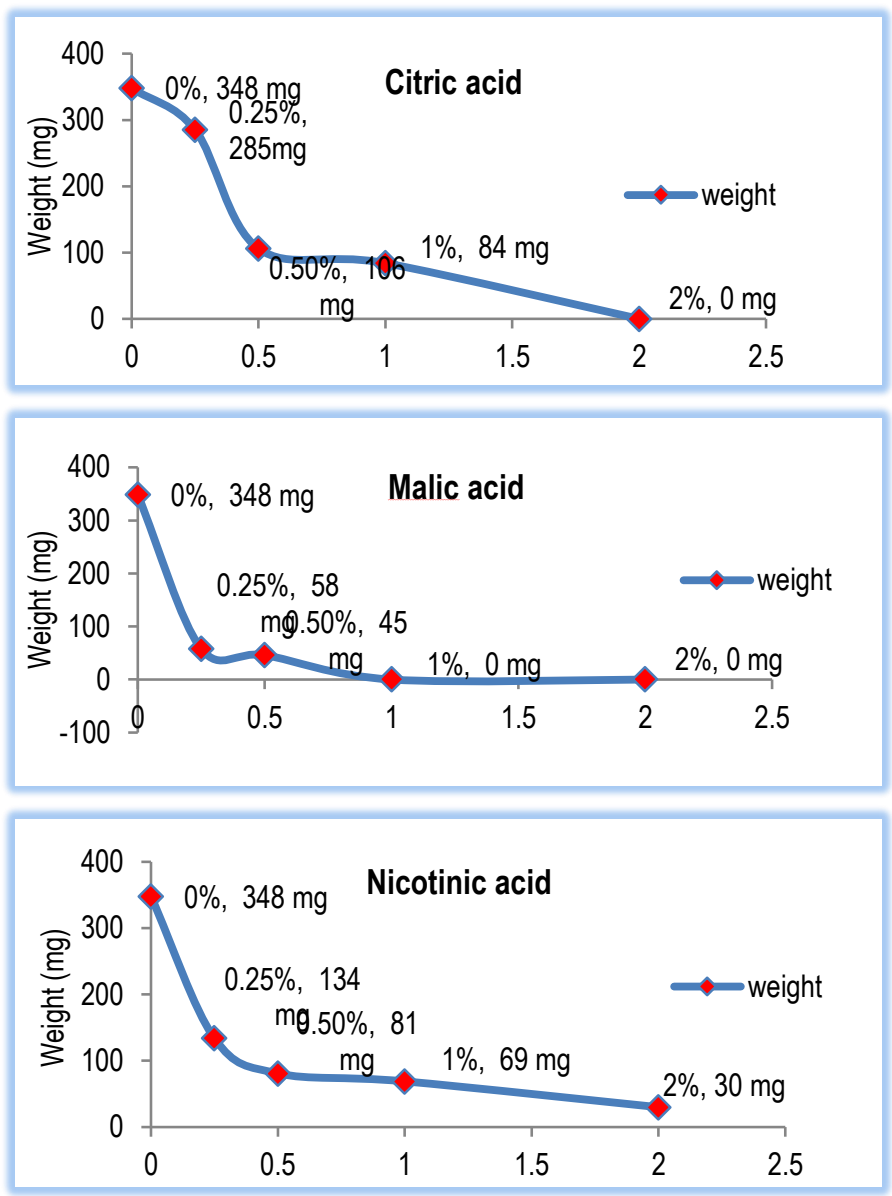

Fig-3 Growth profiling of isolated fungi at different citric acid, malic acid and nicotinic acid concentration

\section{Growth profiling in different temperatures}

When different organisms were grown at different temperatures, they showed different radial growths. Temperature is a vital biochemical factor which controls the enzymatic activities. The fungal samples were grown at different temperature ranges to check the effect of temperature on their growth. At $4^{\circ} \mathrm{C}, 25^{\circ} \mathrm{C}, 30^{\circ} \mathrm{C}$ and $35^{\circ} \mathrm{C}$ the colony radial growth was observed $30 \mathrm{~mm}, 43 \mathrm{~mm}, 35 \mathrm{~mm}$ and $32 \mathrm{~mm}$ with $0.162 \mathrm{gm}, 0.308 \mathrm{gm}, 0.213 \mathrm{gm}$ and $0.119 \mathrm{gm}$ dry weight respectively [Fig-2a].

\section{Growth profiling in different sugar concentrations}

The experiment was conducted to examine the effect of sugar (dextrose) concentrations on the growth of fungus. At $5 \%, 10 \%, 15 \%$ and $20 \%$ sugar concentration, the dry weight was measured $0.376 \mathrm{gm}, 0.422 \mathrm{gm}, 0.348 \mathrm{gm}$ and $0.475 \mathrm{gm}$ respectively [Fig-2c].

\section{Growth profiling in different carbohydrates}

The fungal growth also influenced by different carbohydrate sources. Experiments were conducted to examine the effect of carbohydrates on the growth of fungus. The mycelial dry weight on fructose, sucrose, glucose, maltose and lactose source was $0.190 \mathrm{gm}, 0.457 \mathrm{gm}, 0.309 \mathrm{gm} 0.435 \mathrm{gm}$ and $0.293 \mathrm{gm}$ respectively [Fig-2d].

Growth profiling in different citric, malic and nicotinic acid concentrations Four different concentrations $(0.25 \%, 0.5 \%, 1 \%$ and $2 \%)$ of citric, malic and nicotinic acid showed the different growth profile of the isolated fungal strain. The fungi could not grow at $2 \%$ concentration of citric acid and $1 \%$ concentration of 
malic acid. On the other hand, the growth decreased as the concentrations approached that of nicotinic acid [Fig-3].

\section{Study on cellulolytic activity}

According to the study, after incubation period the isolated fungal strain didn't degrade the cellulose strip. So, cellulolytic activity was not observed by the isolated fungi.

\section{Molecular characterization}

In gel electrophoresis, isolated genomic DNA was of high molecular weight and was seen on top of the highest band (7000 bp approximately) of 5000 bp DNA marker. To confirm the identity of the bacterial isolates and draw phylogenic relationship, the 'ITS' region of ribosomal DNA was amplified and sequenced. PCR amplified fragment was approximately $550 \mathrm{bp}$ in compared to $5000 \mathrm{bp}$ DNA marker (DL5000 DNA Marker, TSINGKE). The 511 bp sequenced nucleotide sequence was performed for a BlastN search in GenBank (https://www.ncbi.nlm.nih.gov). It was revealed that, the strains had approximately $90 \%$ similarity with several Cercospora spp. The obtained sequence deposited in GenBank (accession No. MG735450). The sequences of different Cercospora spp. were downloaded in FASTA format from GeneBank. The data was aligned and phylogenetic tree was constructed using MEGA 6 software [Fig-4].

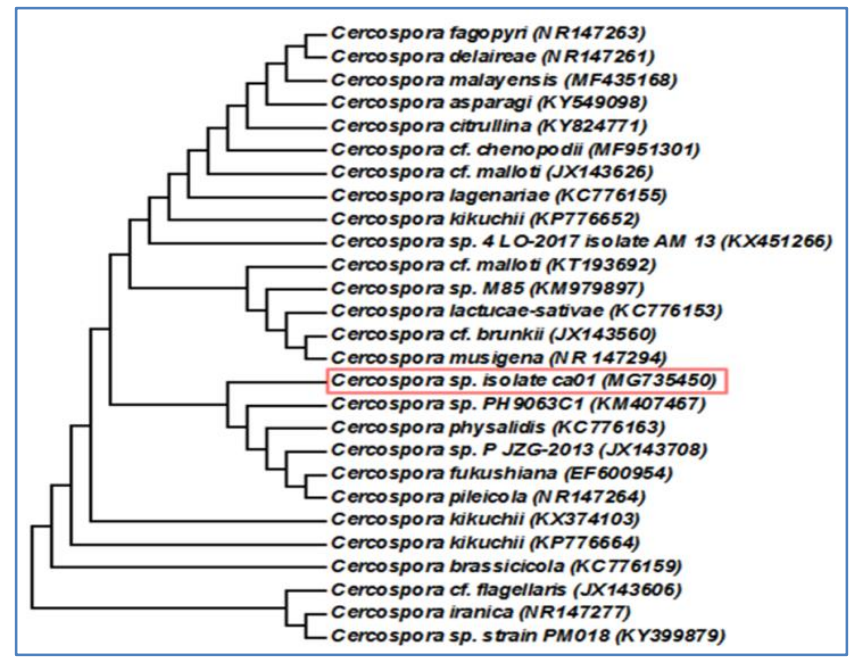

Fig-4 Evolutionary relationships of taxa (timetree): The evolutionary history was inferred using the Neighbor-Joining method. Divergence times for all branching points in the topology were calculated with the RelTime method using the branch lengths contained in the inferred tree. The analysis involved 27 nucleotide sequences. All positions containing gaps and missing data were eliminated. There was a total of 458 positions in the final dataset. Evolutionary analyses were conducted in MEGA 6.

\section{Discussion}

The present study was conducted to identify the causal agent of leaf spot disease of okra. The initial study showed that, the symptoms of the disease was similar to that of the Cercospora leaf spot disease as described by Chupp [14], Deighton [15], Chauhan, et al. [20], Diwakar, et al. [21], Crous, et al. [30], Kamal [31] and Rooney-Latham, et al. [32]. The fungal pathogen was isolated from infected leaf by single spore isolation technique. Brownish white and cottony to fluffy mycelia were observed on PDA media. Microscopic observation showed that, conidiophores were pale brown, septate and arises through the stomata. Conidia were straight to slightly curved, thin walled, multi septate. On the basis of morphological and microscopic observation, the pathogen was identified as Cercospora spp. as described by Deighton [15], Farrag [17], Meghvansi, et al. [22], Ellis and Everhart [28], Narayan, et al. [29], Rahman, et al. [33] and Park, et al. [34]. Several tests were performed to measure the growth profile and characterize the isolated fungi.

Present findings showed that, maximum growth of the isolated fungi occurred at
$\mathrm{pH} 5$ to 6.0 indicating that the fungus preferred acidic to neutral $\mathrm{pH}$. The growth marked decline as the $\mathrm{pH}$ of the medium become either extreme acidic or alkaline. The fungus showed maximum $40 \mathrm{~mm}$ and $43 \mathrm{~mm}$ mycelial growth after 7 days of incubation period at $\mathrm{pH} 5$ and 6.0 with $0.376 \mathrm{gm}$ and $0.423 \mathrm{gm}$ of dry weight respectively. Maximum growth of Cercospora abelmoschi at pH 5.0 was also reported by Sridharan and Rangaswamy [18], which confirms the above results. The present study revealed the differences in temperature optima for mycelial growth and asexual fructification of the fungi. The fungal strain had optimal growth at $25^{\circ} \mathrm{C}$ and poor growth at $35^{\circ} \mathrm{C}$ and $4^{\circ} \mathrm{C}[35,36]$. A research of earlier literature revealed that $\mathrm{C}$. abelmoschi grew well at $25^{\circ} \mathrm{C}$ in artificial culture while sporulation occurred in the $30^{\circ} \mathrm{C}[18,37]$. It was observed that increasing sugar concentrations had a stimulatory effect on growth of the fungi. At $20 \%$ sugar concentration, the highest growth was $46 \mathrm{~mm}$ with $0.475 \mathrm{gm}$ dry weight compared with other concentrations [38]. At this concentration, it gave maximum production of biomass which was achieved within the 7 days of incubation periods. The growth and sporulation of several fungi is governed by nutritional and environmental factors [39]. For the growth profiling of the fungi different carbohydrates; sucrose, fructose, maltose, glucose and lactose were used at $20 \mathrm{gm} / \mathrm{L}$ concentration in PDA media [40]. The maximum growth of the fungi was observed in sucrose with $43 \mathrm{~mm}$ diameter of mycelium growth with $0.457 \mathrm{gm}$ of dry weight. It was also observed that, on fructose source, the growth was lowest with $38 \mathrm{~mm}$ diameter with $0.190 \mathrm{gm}$ mycelium dry weight [41]. The aerial and vegetative mycelium colors also differ slightly in different carbohydrates. The effect on the growth of the fungal strain was studied using different concentrations of citric, malic and nicotinic acid as described by Conkova, et al. [42], Pelaez, et al. [43] and Hassan, et al. [44]. It was observed that the growth of the fungus decreased as the concentrations approached that of citric acid and malic acid. No growth of the fungi was observed at the concentration of $1 \%$ malic acid and $2 \%$ citric acid. In case of nicotinic acid, the lowest growth was observed at $2 \%$ concentration with $30 \mathrm{mg}$ of mycelium dry weight. According to the study, the isolated fungal strain didn't degrade the cellulose strip, so there was no cellulolytic activity was present in the isolated fungi. A BlastN search in GenBank using the $511 \mathrm{bp}$ ITS sequence revealed that the strain showed 90\% similarity with several sequences of Cercospora spp. The obtained sequence deposited in GenBank (accession No. MG735450).

\section{Conclusion}

Our present findings revealed the detailed characterization of the causal agent of Cercospora leaf spot disease of okra (Abelmoschus esculentus L.). To control any pathogen, it is very important criteria to know its identity and characteristics. So it is concluded that, our present findings with detailed data will help to control and manage this disease.

\section{Application of research:}

The above findings will not only identify and characterize the pathogen, but also helps in the proper management of the disease.

\section{Acknowledgment / Funding:}

The authors wish to thanks, Ministry of Science and Technology - Government of the People's Republic of Bangladesh for providing financial support to carry the whole work. The authors also thanks to Professor Joarder DNA \& Chromosome Research Lab, Department of Genetic Engineering and Biotechnology, University of Rajshahi for providing lab facilities.

\section{Research Category: Microbiology, Plant pathology}

\section{Abbreviations:}

CLS : Cercospora leaf spot,

BBS : Bangladesh bureau of statistics,

PDA : Potato dextrose agar

\section{*Principle Investigator: Dr Biswanath Sikdar}

University: University of Rajshahi, Rajshahi, 6205, Bangladesh 
Author Contributions: All authors are equally contributed

Author statement: All authors read, reviewed, agree and approved the final manuscript

\section{Conflict of Interest: None declared}

Ethical approval: This article does not contain any studies with human participants or animals performed by any of the authors.

\section{References}

[1] Oyelade O.J., Ade-Omowaye B.I.O. and Adeomi V.F. (2003) Journal of Food Engineering, 57, 111-114.

[2] Lengsfeld C., Titgemeyer F., Faller G. and Hensel A. (2004) J Agric Food Chem., 52, 1495-1503.

[3] Kumar R., Patil M.B., Patil S.R. and Paschapur M.S. (2009) Intl. J Pharm Tech Res., 1, 658-665.

[4] Khomsug P., Thongjaroenbuangam W., Pakdeenarong N., Suttajit M. and Chantiratikul P. (2010) Research Journal of Biological Sciences, 5, 310313.

[5] Ramachandran S., Sandeep V.S., Srinivas N.K. and Dhanaraju M.D. (2010) Intl. J Research \& Reviews, 9, 132.

[6] Sabitha V., Ramachandran S., Naveen K.R. and Panneerselvam K. (2013) Journal of Pharmacy, Bioallied Sciences, 3(3), 397-402.

[7] Fan S., Zhang Y., Sun Q., Yu L., Li M. and Huang C. (2014) The Journal of Nutritional Biochemistry, 16, 247-258.

[8] Gemede H.F., Haki G.D., Beyene F., Woldegiorgis A.Z. and Rakshit S.K. (2015) Food Science \& Nutrition, 4(2), 223-33.

[9] Hamon S. and Sloten van D.H. (1995) John Wiley \& Sons, 605 Third Avenue, New York.

[10] Holser R. and Bost G. (2004) Journal of the American Oil Chemists' Society, 81, 795-797.

[11] Kumar S., Dagnoko S., Haougui A., Ratnadass A., Pasternak D. and Kouame C. (2010) African Journal of Agricultural Research, 5, 359-368.

[12] Messing J., Thöle C., Niehues M., Shevtsova A. and Glocker E. (2014) PLoS One, 5, 124.

[13] BBS (Bangladesh bureau of statistics) (2014-2015) Agricultural wing, Summary Crop Statistics.

[14] Chupp E. (1954) Ithaca, New York.

[15] Deighton F.C. (1979) Mycological Papers, 144(56).

[16] Dharam, S., Maheshwari V.K. and Gupta A. (2001) Seed Res., 29(2), 254256.

[17] Farrag E.S.H. (2011) Plant Pathology Journal, 10, 175-180.

[18] Sridharan R. and Rangaswami G. (1968) Indian Phytopathology, 21 (1), 37 41.

[19] Deighton F.E. (1973) Trans. Brit. Mycol. Soc., 21, 107-120.

[20] Chauhan M.S., Dhankar B.S. and Duhan J.C. (1980) MACCO Agricultural Digest, 5, 17-18

[21] Diwakar M.P., Rajput J.C. and D'Souza T.F. (1986) Pesticides, 20, 34-74.

[22] Meghvansi M.K., Khan M.H., Gupta R., Veer V. (2013) Research in Microbiology, 164(9), 894-902.

[23] Thomas R.H. (1943) Phytopathology, 33, 114-125.

[24] Beckman P.H. and Payne G.A. (1983) Phytopathology, 73, 286-289.

[25] Enikuomehin 0.A. (2005) J. Trop. Agric., 43, 19-23.

[26] Khare C.P., Nema S., Srivastava J.N., Yadav V.K. and Sharma N.D. (2016) Springer, New Delhi.

[27] Calpouzos L. and Stallknecht G.F. (1967) Phytopathology, 57(7), 799-780.

[28] Ellis J.B. and Everhart B.M. (1893) Journal of Inst. Jamiaca, 1, 347.

[29] Narayan S., Kharwar R.N. and Singh R.K. (2001) Indian Phytopath, 54(3), 351-357.

[30] Crous P.W., Groenewald J.Z., Groenewald M., Caldwell P., Braun U. and Harrington T.C. (2006) Stud. Mycol., 55, 189-197.

[31] Kamal (2010) Bishen Singh Mahendra Pal Singh, Dehra Dun, India.
[32] Rooney-Latham S., Sohek H.J. and Walber T.M. (2011) Plant Dis., 95, 224224.

[33] Rahman M.A., Ali M., Mian I.H., Begum M.M. and Kalimuddin M. (2000) Bangladesh J Plant Pathol, 16(1/2), 31-34.

[34] Park S.H., Choi I.Y., Lee W.H., Lee K.J., Galea V. and Shin H.D. (2017) Mycobiology, 45(2), 114-118.

[35] Lyda S.D., Chen M.D. and Halliwell R.S. (1979) Phytopathology, 69, I-A7.

[36] Silva M.G., Pozza E.A., Lima C.V.R.V.D. and Fernandes T.J. (2016) Ciênc. agrotec., 40, 2.

[37] Kilpatrick R.A. and Johnson H.W. (1956) Phytopathology, 46, 180-181.

[38] Khandar R.R., Bhatnagar H.K. and Rawal P.P. (1985) Indian Journal of Mycology, Plant Pathology, 15, 165-170.

[39] Parmegiani R.M. and Pisano M.A. (1974) Ind. Microbiol., 15, 318.

[40] Third K.S. and Mandahar C.U. (1974) Proc. Natl. Acad. Sci. India, Sect. B (Biol. Sci), 34(4), 387-393.

[41] Veiga P. and Kimati H. (1979) Abstr., 2:21.

[42] Conkova E., Para L. and Kocisova A. (1993) Vet Med (Praha), 38(12), 723 727.

[43] Pelaez A.M.L., Catano C.A.S., Yepes E.A.Q., Illarroel R.R.G., Antoni G.L.D. and Giannuzzi L. (2012) Food Control, 24, 177-183.

[44] Hassan R., Sherif El-Kadi and Mostafa S. (2015) International Journal of Advances in Biology (IJAB), 2, 1. 